\title{
KEGIATAN EKSTRAKURIKULER FUTSAL PADA ANAK PEREMPUAN
}

\author{
Meilinda Khadijah ${ }^{1}$; Nila Fitria ${ }^{1}$ \\ ${ }^{1}$ Program Studi Pendidikan Guru Pendidikan Anak Usia Dini, Fakultas Psikologi dan Pendidikan, \\ Universitas Al-Azhar Indonesia, Jalan Sisingamangaraja, Kebayoran Baru, Jakarta Selatan 12110 \\ Penulis untuk Korespondensi/E-mail: nilafitria@uai.ac.id
}

\begin{abstract}
Abstrak - Pertumbuhan dan perkembangan anak dapat berkembang dengan optimal apabila anak diberi stimulasi yang sesuai dengan tahapan perkembangannya. Olahraga futsal merupakan salah satu kegiatan yang dapat menstimulasi perkembangan anak, termasuk anak usia 5-6 tahun. Saat ini olahraga futsal digemari oleh anak perempuan, namun belum banyak sekolah yang mengadakan ekstrakurikuler futsal untuk anak perempuan. Penelitian ini bertujuan untuk menggambarkan kegiatan ekstrakurikuler futsal pada anak perempuan usia 5-6 tahun. Metode penelitian yang digunakan adalah kualitatif dengan pendekatan kualitatif deskriptif. Teknik pengumpulan data yang digunakan ialah wawancara, observasi dan dokumentasi. Sumber data pada penelitian ini adalah kepala sekolah, pelatih futsal, guru pendamping futsal dan anak perempuan yang mengikuti ekstrakurikuler futsal di TK Islam Al Azhar 45 Grand Depok City. Kesimpulan yang diperoleh adalah kegiatan ekstrakurikuler futsal di TK Islam Al Azhar 45 Grand Depok City meningkatkan kemampuan anak dalam melakukan gerakan tubuh secara terkoordinasi untuk melatih kelenturan, keseimbangan, kelincahan dan anak mampu melakukan permainan fisik dengan aturan. Adapun proses pemilihan ekstrakurikuler di TK Islam Al Azhar 45 Grand Depok City dilakukan secara dua tahap, yaitu pembagian angket saat diadakannya parents meeting dan dilakukannya trial 1 (satu) kali.
\end{abstract}

Kata Kunci: Ekstrakurikuler, Futsal, AnakPerempuan.

Abstract - Growth and development of the child can develop optimally if children are given appropriate stimulation stage of development. Futsal is one of the activities that can stimulate the development of children, including children age 5-6 years. Currently futsal has been popular by girls, but not many schools that organize extracurricular futsal for girls. This study aims to describe futsal extracurricular activities for girls age 5-6 years. The method used is a qualitative research with descriptive approach. The techniques of data collecting used are interviews, observation and documentation. Sources of data in this study are the principal, coach of futsal, futsal accompanying teachers and girls who join extracurricular futsal in TK Islam Al Azhar 45 Grand Depok City. The conclusion is the futsal extracurricular activities at TK Islam Al Azhar 45 Grand Depok City are able coordinated body movement to train flexibility, balance, agility and children are able to physical play by the rules. As for the electoral process at TK Islam Al Azhar 45 Grand Depok City carried out in two stages, namely the distribution of questionnaires when parents meeting and doing trial 1 (one) time. Futsal is one of the activities that can train aspects of child motor development.

Keyword: Extracurricular, Futsal, Girl 


\section{PENDAHULUAN}

A nak usia dini merupakan anak pada rentang usia 0-6 tahun, yang berada dalam proses perkembangan unik. Dikatakan unik, karena proses perkembangannya (tumbuh kembang) terjadi bersamaan dengan masa golden age. Golden age yaitu masa keemasan, dimana segala kelebihan atau keistimewaan yang dimiliki pada masa ini tidak akan terulang untuk kedua kalinya. Kondisi ini merupakan suatu peluang emas yang dapat memacu perkembangan kehidupan anak, sehingga dibutuhkan kondisi dan stimulasi yang sesuai dengan kebutuhan anak (Depdiknas, 2009). Terdapat enam aspek perkembangan anak usia dini yang harus dikembangkan, sebagaimana yang tertulis dalam Peraturan Menteri Pendidikan dan Kebudayaan Republik Indonesia Nomor 137 tahun 2014. Keenam aspek ini berperan penting dalam kehidupan sehari-hari. Salah satu aspek perkembangan tersebut adalah motorik kasar. Aspek perkembangan motorik kasar perlu dikembangkan sebagaimana aspek perkembangan lainnya.

Ketika anak memasuki usia sekolah, anak dapat diberikan stimulasi tambahan dengan mengikuti kegiatan ekstrakurikuler untuk mengembangkan minat dan bakat anak yang dapat terlihat saat usia emas ini. Menurut Sudirman (2015), Ekstrakurikuler dalam pendidikan dimaksudkan sebagai jawaban atas tuntutan dari kebutuhan peserta didik, membantu mereka yang kurang, memperkaya lingkungan belajar dan memberikan stimulasi kepada mereka agar lebih kreatif. Sedangkan menurut Wiyani (2013), kegiatan ekstrakurikuler merupakan kegiatan pendidikan di luar jam pelajaran yang ditunjukan untuk membantu perkembangan peserta didik sesuai dengan kebutuhan, potensi, bakat dan minat melalui kegiatan yang secara khusus diselenggarakan oleh peserta didik dana tau tenaga kependidikan yang berkemampuan dan berkewenangan di sekolah.

Pendapat lain dikemukakan oleh Suryosubroto (2009) bahwa kegiatan ekstrakurikuler adalah kegiatan di luar jam pelajaran tatap muka, dilaksanakan di sekolah atau di luar sekolah agar lebih memperkaya dan memperluas wawasan pengetahuan dan kemampuan yang telah dipelajari dari berbagai mata pelajaran dalam kurikulum. Kesimpulan dari para tokoh adalah ekstrakurikuler merupakan kegiatan yang dibuat oleh satuan pendidikan (sekolah) untuk memberikan stimulasi kepada anak sesuai dengan kebutuhan, potensi, bakat dan minatnya.

Suryosubroto (2009) menjelaskan ada dua jenis kegiatan ekstrakurikuler, yaitu: 1). Kegiatan ekstrakurikuler yang bersifat berkelanjutan, yaitu jenis kegiatan ekstrakurikuler yang dilaksanakan secara terus menerus selama satu periode tertentu. Seperti contoh ekstrakurikuler futsal, menggambar, menari, beladiri dan menyanyi; dan 2). Kegiatan ekstrakurikuler yang bersifat periodik atau sesaat, yaitu kegiatan ekstrakurikuler yang dilaksanakan pada waktu-waktu tertentu. Seperti contoh bakti sosial.

Prinsip Kegiatan Ekstrakurikuler dalam buku Panduan Pengembambangan Diri Peraturan Menteri Pendidikan Nasional Nomor 22 Tahun 2006 juga menjelaskan tentang prinsip-prinsip kegiatan ekstrakurikuler sebagai berikut:

1. Individual, yaitu prinsip kegiatan ekstrakurikuler yang sesuai dengan potensi, bakat, minat peserta didik masing-masing.

2. Pilihan, yaitu prinsip kegiatan ekstrakurikuler yang sesuai dengan keinginan dan diikuti secara sukarela peserta didik.

3. Keterlibatan aktif, yaitu prinsip kegiatan ekstrakurikuler yang menuntut keikutsertaan peserta didik secara penuh.

4. Etos kerja, yaitu prinsip kegiatan ekstrakurikuler dalam suasana yang disukai dan menggembirakan peserta didik.

5. Kemanfaatan sosial, yaitu prinsip kegiatan ekstrakurikuler yang dilaksanakan untuk kepentingan masyarakat.

Setiap kegiatan yang dilakukan, tentu tidak terlepas dari tujuan yang ingin dicapai. Di dalam Peraturan Menteri Pendidikan dan Kebudayaan Republik Indonesia Nomor 62 Tahun 2014 tentang kegiatan ekstrakurikuler ayat 2 yaitu kegiatan ekstrakurikuler diselenggarakan dengan tujuan untuk mengembangkan potensi, bakat, minat, kemampuan, kepribadian, kerjasama dan kemandirian peserta didik secara optimal dalam rangka mendukung pencapaian tujuan pendidikan nasional. 
Salah satu kegiatan ekstrakurikuler yang dapat diberikan kepada anak adalah olahraga futsal. Olahraga futsal merupakan olahraga yang dapat melatih kelenturan, keseimbangan, dan kelincahan anak, melatih anak melakukan koordinasi gerakan antara mata-kaki-kepala serta melatih anak melakukan permainan fisik dengan aturan tertulis dalam Peraturan Menteri Pendidikan dan Kebudayaan Republik Indonesia Nomor 137 tahun 2014.

Futsal diciptakan di Montevido, Uruguay pada tahun 1930, oleh Juan Carlos Ceriani saat piala dunia digelar di Uruguay. Olahraga baru itu dinamai futebol de salao (bahasa Portugis) atau futbolsala (bahasa Spanyol) yang maknanya sama, yakni sepak bola ruangan. Menurut Lhaksana (2011), futsal (futbolsala) dalam bahasa Spanyol berarti permainan sepakbola yang dilakukan di dalam ruangan. Sedangkan menurut Sugono (2008), Futsal adalah olahraga permainan sepakbola, dengan lapangan dan gawang lebih kecil, biasanya dimainkan di dalam ruangan besar, masing-masing tim terdiri atas lima orang.

Menurut Tenang (2008) aturan permainan futsal berbeda dengan aturan sepakbola di lapangan besar atau di lapangan rumput. Mulai dari ukuran lapangan dan bola, jumlah pemain, hingga system pertandingan. Menurut Tenang (2008) FIFA (Fédération Internationale de Football Association) sebagai induk olahraga futsal telah mengeluarkan peraturan yang mencakup seluruh hal yang berhubungan dengan permainan futsal. Berikut adalah informasi mengenai ukuran lapangan futsal dan peraturan resmi permainan futsal berdasarkan peraturan FIFA, sebagai berikut: Lapangan Futsal; Bola; Jumlah pemain; Lama Permainan; dan, Gawang.

Teknik-teknik yang digunakan dalam permainan futsal tidak jauh berbeda dengan permainan sepak bola. Namun, karena faktor lapangan futsal yang relatif lebih kecil dan permukaan lantainya lebih rata menyebabkan perbedaan-perbedaan penggunaan teknik. Menurut Lhaksana (2011), modern futsal adalah permainan futsal yang para pemainnya diajarkan bermain dengan sirkulasi bola yang sangat cepat, menyerang dan bertahan, dan juga sirkulasi pemain tanpa bola ataupun timing yang tepat. Berikut adalah teknik dasar bermain futsal: Passing bola; Control bola; Dribbling bola; Shooting bola; Heading bola; Blocking bola; dan Melempar Bola.

Dampak positif lain dari olahraga futsal adalah membentuk kerjasama dalam tim. Dalam kegiatan ekstrakurikuler umumnya anak akan bertemu dengan teman-teman baru dan dalam beberapa hal anak harus mencoba bekerjasama dengan mereka dalam sebuah tim. Hal ini mengajarkan anak untuk berkomunikasi dan berkoordinasi sejak dini dan dapat meningkatkan rasa percaya diri anak dalam bersosialisasi. Saat ini olahraga futsal tidak hanya dimainkan oleh laki-laki saja, tetapi perempuan sudah mulai bermain futsal.

Saat ini Indonesia pun sudah memiliki tim nasional futsal perempuan. Perkembangan futsal perempuan ini dirasakan sangat pesat karena, kini di berbagai sekolah sudah banyak yang membuka kegiatan ekstrakurikuler futsal untuk perempuan.Walaupun ekstrakurikuler futsal untuk perempuan ini baru ada di jenjang pendidikan menengah atas dan universitas. Tetapi, bisa terlihat dengan keadaannya saat ini bahwa perempuan juga memiliki minat yang besar terhadap kegiatan futsal yang selalu identikdengan olahraga laki-laki. Tidak hanya itu di Indonesia sudah semakin marak diadakannya pertandingan futsal perempuan dan hal tersebut membuat minat perempuan untuk bermain futsal semakin tinggi (futsalin.id, 2014).

Berdasarkan masalah yang peneliti temukan hampir seluruh TK sudah menjadikan futsal menjadi kegiatan ekstrakurikuler di sekolah. Namun, masih banyak TK yang tidak mengizinkan anak perempuan untuk mengikuti kegiatan ekstrakurikuler futsal karena, masih banyak yang menganggap futsal merupakan olahraga untuk anak laki-laki saja. Masih banyak yang merasa keberatan jika anak perempuan mengikuti ekstrakurikuler futsal karena, mereka menganggap bahwa futsal adalah permainan yang menuntut kekuatan fisik. Pendapat inilah yang menghalangi kebebasan anak perempuan dalam mengikuti kegiatan ekstrakurikuler futsal khususnya di TK. Dari hasil observasi yang dilakukan terlihat bahwa di TK Islam Al Azhar 45 Grand Depok City tidak membeda-bedakan gender dalam kegiatan ekstrakurikuler khususnya futsal. Sekitar 5\% anak perempuan (Muznah, 2017) di TK Al Azhar 45 Grand Depok City memiliki 
minat yang besar dalam kegiatan ekstrakurikuler futsal dan sekolah pun memfasilitasinya dengan mengizinkan anak perempuan mengikuti ekstrakurikuler futsal.

Walaupun masih sedikit anak perempuan yang mengikuti kegiatan ekstrakurikuler futsal di TK Islam Al Azhar 45 Grand Depok City, tetapi minat mereka sangat besar pada kegiatan ekstrakurikuler ini. Bisa terlihat saat mereka shooting bola, dribbling bola dan menggocek lawan yang didominasi anak laki-laki. Mereka sangat antusias ketika coach memberi pengarahan dan saattim mereka bertanding di sekolah maupun di luar sekolah ketika melawan klub futsal TK lain.

Berdasarkan uraian permasalahan yang ditemukan maka peneliti tertarik untuk mengetahui gambaran kegiatan ekstrakurikuler futsal pada anak perempuan usia 5-6 tahun yang akan dilakukan di TK Islam Al Azhar 45 Grand Depok City.

\section{METODE PENELITIAN}

Penelitian ini dilakukan di TK Islam AL Azhar 45 grand Depok City, yang berlokasi di jl. Boulevard Raya Grand Depok City, Kalimulya, Cilodong, Kota Depok, Jawa Barat 16413. Waktu penelitian dari penetapan judul sampai proses pelaporan hasil penelitian dilaksanakan dari bulan November 2017 hinggaJuli 2018. Subjek penelitian adalah anak perempuan usia 5-6 tahun yang mengikuti kegiatan ekstrakurikuler futsal, kepala sekolah, guru pendamping dan pelatih futsal.

Berdasarkan permasalahan penelitian, yaitu tentang Kegiatan Ekstrakurikuler Futsal Pada Anak Perempuan Usia 5-6 Tahun di TK Islam Al Azhar 45 Grand Depok City, maka peneliti menggunakan metode penelitian kualitatif, karena permasalahan berhubungan dengan manusia yang secara fundamental bergantung pada pengamatan. Pendekatan yang peneliti gunakan adalah pendekatan kualitatif deskriptif yaitu pendekatan untuk mendeskripsikan dan menggambarkan fenomena-fenomena yang ada dengan rangkaian kegiatan untuk memperoleh data yang bersifat apaadanya dalam kondisi tertentu yang hasilnya lebih menekankan makna. Hal ini seperti yang dikatakan oleh Sukmadinata (2013) bahwa penelitian deskriptif kualitatif ditujukan untuk mendeskripsikan dan menggambarkan fenomena-fenomena yang ada, baik bersifat alamiah maupun rekayasa manusia, yang lebih memperhatikan mengenai karakteristik, kualitas, keterkaitan antar kegiatan.

Sumber data yang digunakan berasal dari dua sumber data, yaitu data primer dan sekunder. Data primer adalah sumber data yang secara langsung memberikan data kepada pengumpul data (Sugiyono, 2010). Sumber primer ini berupa catatan hasil wawancara yang diperoleh melalui wawancara dengan narasumber. Selain itu, pengumpulan data juga dilakukan dengan cara melakukan observasi mengenai situasi kegiatan ekstrakurikuler futsal di TK Islam Al Azhar 45 Grand Depok City. Sementara, sumber data sekunder merupakan sumber data yang tidak memberikan informasi secara langsung kepada pengumpul data. Data ini digunakan untuk mendukung infomasi dari data primer yang diperoleh baik dari wawancara, maupun dari observasi langsung ke lapangan. Penulis juga menggunakan data sekunder hasil dari studi pustaka.

Teknik pengumpulan data yang digunakan adalah observasi, wawancara dan dokumentasi. Menurut Sugiyono (2010), observasi digolongkan menjadi empat bagian yaitu, partisipasi aktif, partisipasi moderat, observasi terus terang atau tersamarkan, dan partisipasi lengkap. Di dalam penelitian ini digunakan observasi pasif dikarenakan peneliti hanya mengamati kegiatan tanpa ikut terlibat dalam kegiatan atau aktivitas anak tersebut.

Terkait dengan metode pengumpulan data dengan wawancara, yang digunakan adalah wawancara terstruktur. Wawancara terstruktur merupakan satu teknik pengumpulan data dengan cara lisan terhadap responden, dengan menggunakan pedoman wawancara yang telah disediakan (Esterberg dalam Sugiyono, 2010). Wawancara dilakukan mulai tanggal 2 Mei 2018. Sementara pengumpulan data dengan dokumen dilakukan dengan mengumpulkan foto-foto atau video yang meliputi data tentang pelaksanaan kegiatan ekstrakurikuler futsal pada anak perempuan usia 5-6 tahun di TK Islam Al Azhar 45 Grand Depok City. Hal tersebut sesuai dengan pendapat Sugiyono (2010) yang mengatakan bahwa dokumen bisa berbentuk tulisan, gambar, atau karya- karya monumental dari seseorang. Dokumen 
merupakan pelengkap dari penggunaan dari metode observasi dan wawancara dalam penelitian kualitatif.

Teknik analisis data yang dilakukan dengan menggunakan teknik analisis data yang dikemukakan oleh Miles dan Huberman (Sugiyono, 2010) yang mencakup reduksi data (data reduction), penyajian data (data display), dan kesimpulan atau verifikasi (conclusion drawing).

Penelitian kualitatif harus mengungkap kebenaran yang objektif. Melalui keabsahan data kredibilitas (kepercayaan) penelitian kualitatif dapat tercapai. Untuk mendapatkan keabsahan data dilakukan triangulasi jenis triangulasi sumber dan triangulasi teknik. Triangulasi sumber ini digunakan oleh peneliti untuk mengecek data yang diperoleh dari kepala sekolah dan pelatih futsal. Peneliti membandingkan hasil wawancara yang diperoleh dari masing-masing sumber atau informan penelitian sebagai pembanding untuk mengecek kebenaran informasi yang didapatkan. Sedangkan triangulasi teknik ini digunakan oleh peneliti setelah mendapatkan hasil wawancara yang kemudian dicek dengan hasil observasi dan dokumentasi.

\section{HASIL DAN PEMBAHASAN}

Kegiatan ekstrakurikuler futsal TK Islam Al Azhar 45 mulai diselenggarakan pada tahun 2013. Ekstrakurikuler futsal TK Islam Al Azhar 45 sudah berjalan kurang lebih 5 tahun. Ekstrakurikuler futsal TK Islam Al Azhar 45 Grand Depok City diselenggarakan untuk mengembangkan aspek perkembangan anak sesuai minatnya dan mengembangkan kemampuan yang dimiliki oleh anak. Ekstrakurikuler futsal dilakukan 2 kali dalam seminggu yaitu hari Senin dan Kamis, dimulai dari pukul 11.00 sampai 12.00 di lapangan indoor TK Islam Al Azhar 45.

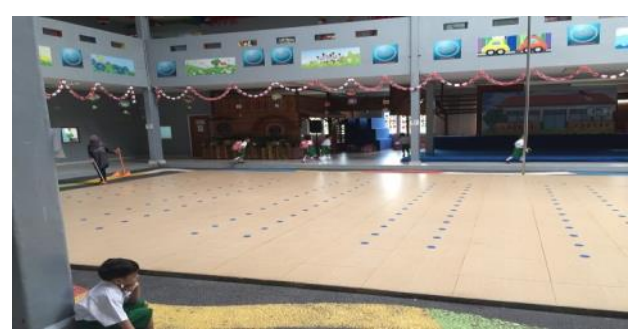

Gambar 2. Lapangan indoor TK Islam Al Azhar 45 Grand Depok City
Ekstrakurikuler futsal dilakukan setelah kegiatan belajar mengajar di kelas selesai, seperti yang dikatakan oleh Mulyana (2011) bahwa kegiatan ekstrakurikuler adalah kegiatan yang dilakukan di luar jam pelajaran yang bertujuan untuk melatih siswa pada pengalaman-pengalaman nyata. Jadi, kegiatan ekstrakurikuler futsal dilakukan setelah jam pelajaran yang mempunyai tujuan untuk melatih anak dalam mengembangkan aspekaspek perkembangan anak sesuai usianya khususnya aspek fisik motorik, kognitif dan sosial emosional anak untuk mencapai kematangan yang sempurna pada masa-masa perkembangan selanjutnya.

Lapangan indoor yang dimiliki oleh TK Islam Al Azhar 45 Grand Depok City memiliki ukuran $6 \mathrm{~m} \times 3 \mathrm{~m}$. Kalau dibandingkan dengan ukuran lapangan futsal sesungguhnya ukuran lapangan di TK Islam Al Azhar 45 Grand Depok City ini tidak sesuai standard yang ada, tetapi untuk anak-anak ukuran lapangan ini sudah cukup. Fasilitas yang dimiliki pun semuanya aman untuk anak-anak dan lengkap sesuai kebutuhan ekstrakurikuler futsal, seperti gawang, bola futsal, ladder, marker dan cone.

Ekstrakurikuler futsal TK Islam Al Azhar 45 dilaksanakan di lapangan indoor yang berada di dalam lingkungan sekolah. Dalam hal ini pelaksanaan ekstrakurikuler di TK Islam Al Azhar 45 telah sesuai dengan apa yang dikatakan oleh Lhaksana (2011) bahwa futsal (futbolsala) dalam bahasa Spanyol berarti permainan sepakbola yang dilakukan di dalam ruangan.

Ekstrakurikuler futsal TK Islam Al Azhar 45 dari awal sudah dilatih oleh coach yang bernama SR beserta asistennya bernama RD. Ekstrakurikuler futsal juga didampingi oleh guru bernama FH. Ibu FH sudah menjadi guru pendamping selama 2 tahun ini. Berdasarkan hasil penelitian coach futsal dengan guru pendamping berkontribusi dengan baik dalam kegiatan ekstrakurikuler maupun saat pertandingan di luar sekolah. Coach Futsal memiliki perencanaan dan penilaian yang digunakan saat melatih futsal. Untuk penilaian coach futsal melihat perkembangan keterampilan yang dimiliki anak selama latihan berlangsung, apakah keterampilannya meningkat atau tidak setiap minggunya, seperti contohnya coach melihat kemampuan 
menangkap anak setelah coach memberikan materi dan saat dicoba anak bisa lalu dikombinasikan juga bisa seperti dribblecontrol berarti anak sudah paham dan dilihat saat pertandingan juga. Sedangkan, perencanaan yang dilakukan oleh coach futsal yaitu dengan menjadwalkan apa yang harus dilakukan setiap melatih futsal.

Tabel 1. Perencanaan Ekstrakurikuler Futsal

\begin{tabular}{|l|l|}
\hline \multicolumn{2}{|c|}{ Perencanaan Ekstrakurikuler Futsal } \\
\hline Pemanasan (Lari) & Setiap latihan \\
\hline Passing & $2-3$ kali \\
\hline Dribbling & $2-4$ kali \\
\hline Control & $2-3$ kali \\
\hline Shooting & $2-3$ kali \\
\hline
\end{tabular}

Berdasarkan hasil wawancara, kegiatan ekstrakurikuler futsal TK Islam Al Azhar 45 merupakan ekstrakurikuler berkelanjutan dari anak kelompok A. Dikatakan berkelanjutan karena, tidak tersedianya waktu pergantian ekstrakurikuler jika anak atau orangtua menginginkan pindah ekstrakurikuler lain. Dalam kegiatan ekstrakurikuler futsal selalu ada kontribusi antara pelatih dengan guru, ketika saat latihan ataupun saat pertandingan.

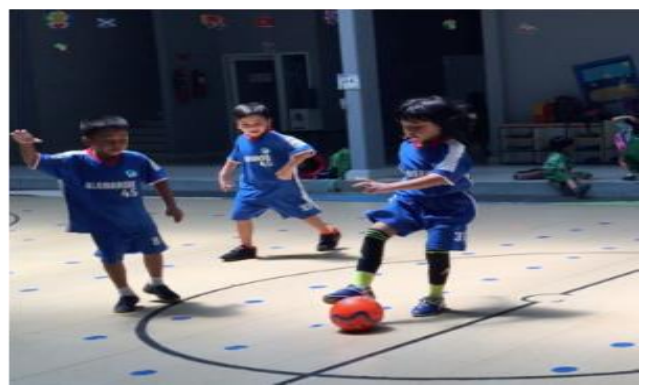

Gambar 3. Anak melakukan teknik control bola

Kemampuan fisik motorik anak perempuan dalam ekstrakurikuler futsal terlihat dari kegiatan yang dilakukan saat ekstrakurikuler futsal yaitu berlari. Sebelum latihan futsal dimulai, maka semua anak-anak yang mengikuti ekstrakurikuler futsal diwajibkan untuk melakukan pemanasan berkeliling lapangan sebanyak 2 kali. Kemampuan fisik motorik yang biasa dilakukan oleh coach, anak perempuan juga dapat mengikutinya walaupun kemampuan motorik anak perempuan berbeda dengan anak laki-laki yang mengikuti ekstrakurikuler futsal. Selain kemampuan motorik, terlihat juga bahwa kemampuan kognitif anak perempuan berkembang saat mengikuti ekstrakurikuler futsal terlihat saat anak menggunakan strategi untuk menggocek lawan dan saat mereka menggunakan teknikteknik dasar futsal. Kemampuan sosial emosional anak juga terlihat ketika bermain futsal yaitu anak mentaati aturan-aturan yang telah diajarkan oleh coach dan anak perempuan juga dapat bersosialisasi dengan timnya yang didominasi oleh anak laki-laki.

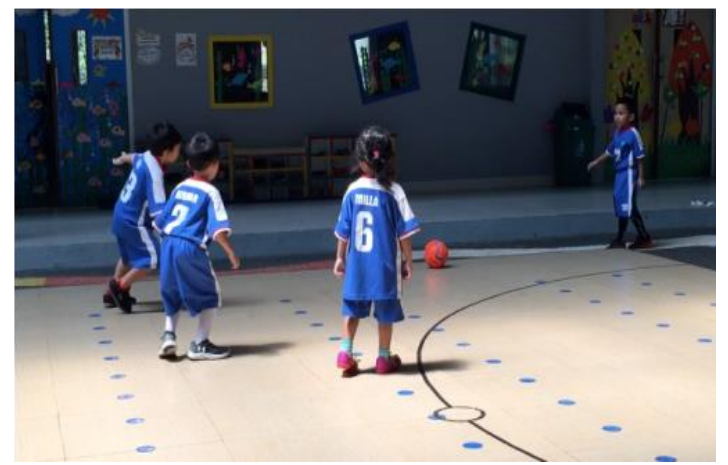

Gambar 4. Anak mentaati aturan

Berdasarkan hasil wawancara dengan pelatih futsal dan guru pendamping diketahui bahwa keragaman motorik anak perempuan dalam ekstrakurikuler futsal yang harus mereka kuasai dalam teknik-teknik dasar futsal adalah control bola, karena jika anak sudah menguasai teknik control bola maka anak akan menguasai teknikteknik dasar lainnya. Kemampuan motorik lain yang dimiliki anak perempuan dalam teknikteknik dasar futsal yaitu mereka dapat melakukan passing kepada teman satu timnya walaupun tidak selincah dengan teknik passing yang dilakukan oleh anak laki-laki.

Selain kemampuan motorik, kegiatan ekstrakurikuler ini juga menstimulasi perkembangan lainnya khususnya kognitif dan sosial emosional anak. Dapat terlihat ketika coach mengadakan pertandingan saat latihan pun mereka juga melakukan apa yang dilakukan oleh anak laki-laki. Anak yang berinisial $M$ melakukan teknik-teknik dasar futsal saat timnya bertanding dengan tim yang dominan anak laki-laki. Melakukan teknik passing terhadap teman satu timnya, melakukan teknik control ketika temannya memberikan bola dan melakukan teknik blocking saat $\mathrm{M}$ menjadi untuk melindungi gawang timnya. Anak yang berinisial C juga sudah menguasai teknik-teknik dasar futsal yang diajarkan oleh pelatih. Seperti saat melakukan teknik kontrol terhadap bola dan teknik blocking terhadap lawan. Anak yang 
berinisial $S$ sudah menguasai teknik-teknik dasar futsal terlihat saat latihan, walaupun teknik yang dikuasai oleh $\mathrm{S}$ lebih menguasai teknik passing kepada teman satu tim saat bertanding melawan tim anak laki-laki.

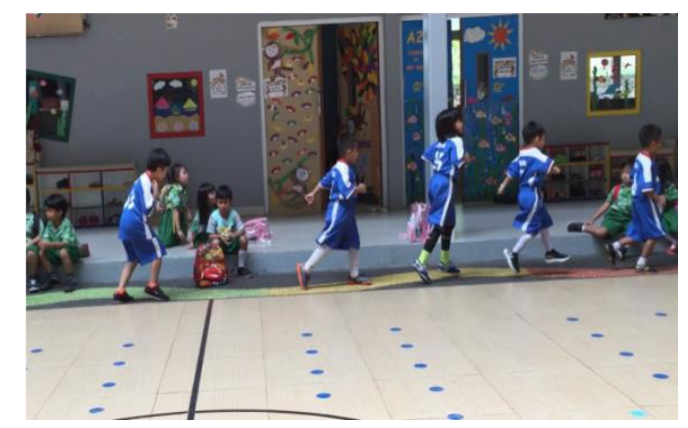

Gambar 5. Anak sedang berlari keliling lapangan

Adapun proses kegiatan ekstrakurikuler futsal selama penelitian, yaitu:

\section{Subjek M}

Subjek M pada hari Kamis, 3 Mei 2018 pukul 11.00-12.00 mengikuti latihan ekstrakurikuler futsal di sekolah dengan menggunakan media bola dan menggunakan metode praktek langsung. Pada latihan hari ini sebelum memulai latihan seperti biasa semua anak-anak yang mengikuti ekstrakurikuler melakukan pemanasan keliling lapangan indoor sebanyak 2 kali dan setelah selesai pemanasan anak-anak baris perkelompok dibagi menjadi 5 tim. Hari ini $\mathrm{M}$ masuk ke dalam tim 2 dan $\mathrm{M}$ menjadi kipper dalam timnya. Melakukan teknik passing (lemparan) saat menjadi kipper terhadap teman satu tim. Ketika menjadi kiper $M$ mampu melemparkan bola kearah teman satu timnya sesuai teknik yang diajarkan oleh pelatih yaitu sebelum melemparkan bola $\mathrm{M}$ harus berlari kecil ke arah lingkaran pembatas yang berada di depan gawang. $\mathbf{M}$ juga melakukan teknik blocking saat menjadi kipper yaitu $\mathrm{M}$ melakukan teknik blocking terhadap tim lawan dan ia juga mempertahankan gawang dari tendangan tim lawan dengan baik.

Subjek M pada hari Senin, 7 Mei 2018 pukul 11.00-12.00 mengikuti latihan ekstrakurikuler futsal di sekolah dengan menggunakan media bola dan menggunakan metode praktek langsung. Hari ini setelah keluar kelas semuanya berbaris dan memulai pemanasan sebelum mulai latihan futsal yang dipimpin oleh coach. M saat latihan menjadi anchor atau bek untuk menyerang tim lawan. Pada latihan ini M menunjukkan kemampuan teknik-tekniknya yang diajarkan oleh coach yaitu M melakukan teknik passing kepada teman satu timnya. M juga melakukan teknik kontrol yaitu teknik menahan bola sebelum diberikan kepada teman satu timnya. Teknik lain yang dilakukan oleh M yaitu teknik dribbling saat bertanding dan teknik blocking terhadap tim lawan.

\section{Subjek C}

Subjek C pada hari Kamis, 3 Mei 2018 pukul 11.00-12.00 mengikuti latihan ekstrakurikuler futsal di sekolah dengan menggunakan media bola dan menggunakan metode praktek langsung. Pada latihan hari ini, setelah $\mathrm{C}$ selesai kelas, ia langsung turun ke bawah dan bergabung dengan teman-temannya untuk berbaris. Sebelum memulai latihan futsal, maka $\mathrm{C}$ beserta teman-temannya melakukan pemanasan dengan keliling lapangan indoor sebanyak 2 kali. Setelah selesai pemanasan latihan futsal dimulai dengan membagi anggota menjadi 5 tim dan $\mathrm{C}$ tergabung dalam tim 3 . Hari ini C menjadi posisi anchor atau bek. C melakukan teknik passing kepada teman satu timnya, C juga melakukan teknik kontrol setelah teman satu timnya memberikan bola kepadanya dengan menahan bola menggunakan telapak kakinya. M juga melakukan teknik blocking yang biasa dilakukan oleh pemain posisi anchor atau bek yaitu dengan melakukan blocking terhadap lawannya.

Subjek C pada hari Senin, 7 Mei 2018 pukul 11.00-12.00 mengikuti latihan ekstrakurikuler futsal di sekolah dengan menggunakan media bola dan menggunakan metode praktek langsung. Pada hari ini, tim C melawan tim M. Setelah melakukan pemanasan keliling lapangan, maka dimulailah latihan futsal. Seperti biasa $\mathrm{C}$ selalu menjadi anchor atau bek pada timnya. Latihan hari ini $\mathrm{C}$ melakukan teknik-teknik yang telah diajarkan oleh coach, yaitu C melakukan teknik passing terhadap teman satu tim, melakukan teknik control dengan menahan bola menggunakan telapak kaki setelah teman satu tim memberikan bola kepadanya dan $\mathrm{C}$ juga. 


\section{Subjek S}

Subjek S pada hari Kamis, 3 Mei 2018 pukul 11.00-12.00 mengikuti latihan ekstrakurikuler futsal di sekolah dengan menggunakan media bola dan menggunakan metode praktek langsung. Pada hari ini S menjadi pemain depan ketika latihan futsal. Sebelum latihan futsal, seperti biasa anak-anak melakukan pemanasan yaitu pemanasan 2 kali keliling lapangan. Ketika latihan futsal dimulai, $\mathrm{S}$ bergabung dengan tim 3 bersama dengan C. Saat bertanding $\mathrm{S}$ melakukan teknik shooting ke a rah gawang walaupun tidak masuk tetapi $S$ selalu mencoba shooting bola ke dalam gawang tim lawan. Selainitu, teknik yang dilakukan $S$ yaitu teknik passing ketika $S$ mengumpan bola kepada teman satu tim.

Subjek S pada hari Senin, 7 Mei 2018 pukul 11.00-12.00 mengikuti latihan ekstrakurikuler futsal di sekolah dengan menggunakan media bola dan menggunakan metode praktek langsung. Hari ini setelah melakukan pemanasan keliling lapangan dimulailah latihan futsal. Hari ini posisi $S$ sama seperti latihan sebelumnya yaitu menjadi pemain depan, maka teknik yang dipakai $\mathrm{S}$ saat bertanding yaitu shooting bola ke arah gawang tim lawan dan passing bola kepad teman satu tim.

Berdasarkan hasil penelitian dapat dilihat bahwa selain mengembangkan aspek fisikmotorik anak kegiatan ekstrakurikuler futsal juga dapat mengembangkan aspek-aspek perkembangan lainnya, yaitu aspek perkembangan kognitif dan aspek perkembangan sosial emosionalnya. Dalam aspek fisik-motorik anak-anak belajar berlari, anak belajar mengontrol bola, anak belajar mengoper bola dan anak belajar bagaimana cara menendang bola yang baik, sebagaimana perkembangan anak usia 5-6 tahun. Kegiatan ekstrakurikuler futsal juga mengembangkan aspek perkembangan kognitif anak, yaitu anak menggunakan strategi saat menggocek bola terhadap lawan dengan menggunakan pola untuk melewatinya. Hal tersebut juga mengembangkan aspek perkembangan sosial emosional dimana anak dapat bermain sesuaiaturan, berkomunikasi dan bekerjasama dengan teman satu timnya.

Berdasarkan hasil penelitian, keterampilan motorik anak perempuan dan anak laki-laki berbeda saat mengikuti ekstrakurikuler futsal. Terlihat saat melakukan latihan maupun pertandingan futsal, bahwa anak laki-laki lebih terampil dalam kemampuan motoriknya dibandingkan dengan anak perempuan. Keterampilan motorik kasar untuk anak lakilaki yang meliputi berlari, melompat, dan keseimbangan, cenderung berkembang lebih cepat dibandingkan anak perempuan. Sebenarnya anak perempuan bisa menyeimbangi keterampilan motorik anak lakilaki, akan tetapi untuk kemampuan menguasai teknik-teknik futsal anak laki-laki lebih lincah dan lebih cepat memahami.

Walaupun keterampilan motorik anak perempuan lebih lambat, akan tetapi keterampilan motorik anak perempuan sudah berkembang dengan baik dan sesuai dengan tingkat pencapaian aspek perkembangan dalam Peraturan Menteri Pendidikan dan Kebudayaan 137 tahun 2014. Terlihat saat latihan keterampilan perkembangan motoriknya anak perempuan $\mathrm{M}, \mathrm{C}$, dan $\mathrm{S}$ berkembang sesuai usianya. Keterampilan motorik anak usia 5-6 tahun dalam Peraturan Menteri adalah melakukan gerakan tubuh secara terkordinasi untuk melatih kelenturan, keseimbangan dan kelincahan, keterampilan motorik ini terlihat pada $\mathrm{M}, \mathrm{C}$ dan $\mathrm{S}$ ketika mereka menunjukan kelincahannya saat menggocek lawan.

Selanjutnya, anak mampu melakukan koordinasi antara gerakan mata-kaki-tangankepala, keterampilan motorik ini juga terlihat saat anak berlatih futsal yaitu ketika M menjadi kiper dimana $M$ dapat melakukan koordinasi gerakan mata-kaki-tangannya saat akan melemparkan bola kepada timnya, $\mathrm{C}$ dan $\mathrm{S}$ juga melakukan keterampilan motorik ini ketika mereka menggunakan teknik-teknik dasar yang dilakukan juga oleh anak laki-laki dan selanjutnya anak mampu melakukan permainan fisik sesuai aturan yang ada seperti contohnya dalam ekstrakurikuler futsal anak-anak perempuan mengerti aturan-aturan yang ada dalam futsal dan macam-macam pelanggaran, walaupun hanya sebatasnya saja seperti handsball. 


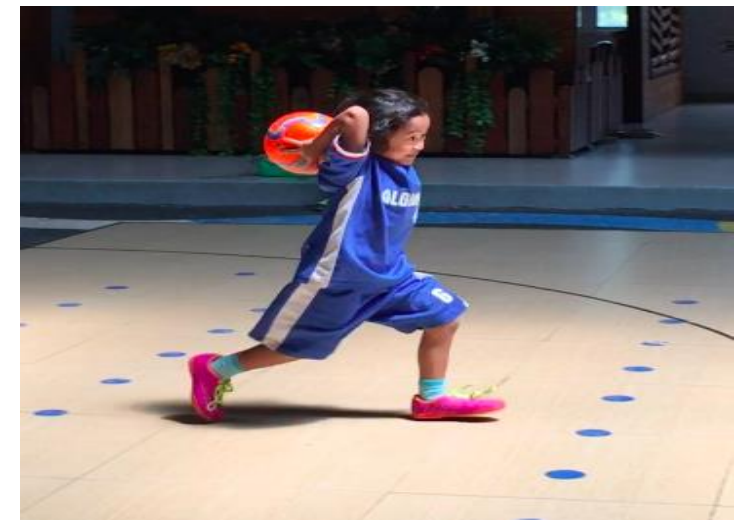

Gambar 6. Anak sedang melemparkan bola saat menjadi kiper

Kegiatan ekstrakurikuler futsal juga melatih keterampilan kognitif anak saat latihan maupun bertanding. Terlihat ketika anak perempuan mengikuti latihan yaitu anak mampu membuat strategi dalam menghadapi tim lawan. Saat latihan terlihat bahwa keterampilan anak perempuan M, C, dan S mampu menggocek tim lawan ketika mereka menjadi pemain depan ataupun belakang. Keterampilan sosial emosional mereka juga berkembang dengan baik sesuai tingkat pencapain sesuai usianya yang tertulis dalam Peraturan Menteri dan Pendidikan 137 Tahun 2014 yaitu M, C, dan S mampu mentaati peraturan yang ada dalam ekstrakurikuler futsal, seperti ketika menjadi kiper M mampu melemparkan bola ke arah teman satu timnya sesuai teknik yang diajarkan oleh pelatih yaitu sebelum melemparkan bola $\mathrm{M}$ harus berlari kecil ke arah lingkaran pembatas yang berada di depan gawang. Selain itu M, C, dan $\mathrm{S}$ juga mampu bersosialisasi dan berkomunikasi dengan timnya yang didominasi oleh anak laki-laki.

\section{SIMPULAN DAN SARAN}

Berdasarkan pembahasan pada sub focus penelitian, maka dapat disimpulkan bahwa ekstrakurikuler futsal pada anak perempuan usia 5-6 tahun di TK Islam Al Azhar 45 Grand Depok City sudah berjalan sesuai tujuannya yaitu melatih anak dalam mengembangkan aspek-aspek perkembangannya sesuai usia dalam Peraturan Menteri Pendidikan dan Kebudayaan Nomor 137 Tahun 2014. Aspek fisik motorik yang tertulis dalam Peraturan Menteri Pendidikan dan Kebudayaan Nomor 137 Tahun 2014 yaitu anak mampu melakukan gerakan tubuh secara terkoordinasi untuk melatih kelenturan, keseimbangan, dan kelincahan, anak mampu melakukan koordinasi gerakan mata-kaki- tangan-kepala dan anak mampu melakukan permainan fisik dengan aturan, untuk perkembangan kognitif yaitu anak mampu mengenal pola dan sosial emosional anak mampu mentaati suatu aturan dalam kegiatan ekstrakurikuler futsal.

Adapun saran yang dapat disampaikan adalah agar keragaman gerak anak perempuan lebih terampil, maka coach atau guru pendamping bisa menambahkan kegiatan yang dapat mengasah keterampilan motorik kasar anak saat pemanasan, seperti melompat dan menjaga keseimbangan.

\section{DAFTAR PUSTAKA}

Depdiknas. (2009). Peraturan Menteri Pendidikan Nasional Republik Indonesia Nomor 58 Tahun 2009 tentang standar pendidikan anak usia dini.

Lhaksana, J.,Pardosi, I.H. (2008). Inspirasi dan spirit futsal. Depok: Raih Asa Sukses.

Lhaksana, J. (2011). Taktik \& strategi futsal modern. Depok: Penebar Swadaya Group.

Peraturan Menteri Pendidikan dan Kebudayaan Republik Indonesia Nomor 137 Tahun 2014 tentang standar nasional pendidikan anakusia dini.

Peraturan Menteri Pendidikan Republik Indonesia Nomor 62 Tahun 2014 tentang kegiatan ekstrakurikuler pada pendidikandasar dan pendidikan menengah.

Rohmat, M. (2011). Mengartikulasikan Pendidikan Nilai. Bandung: Alfabeta.

Samsudin. (2008). Pembelajaran motorik di taman kanak-kanak. Jakarta: Litera.

Sulaeman, M.M., Homzah, S. (2010). Kekerasan terhadap perempuan (tinjauan dalam berbagai disiplin ilmu dan kasus kekerasan). Bandung. Revika Aditama.

Sudirman, A. (2015). Management of student development. Riau: Yayasan Indragiri.

Sugiyono. (2010). Metode penelitian kuantitatif, kualitatif, dan R\&D. Bandung: Alfabeta.

Sukmadinata, N.S. (2013). Metode penelitian pendidikan. Bandung: PT Remaja Rosdakarya.

Suryosubroto, B. (2009). Proses belajar mengajar di sekolah. Jakarta: Rineka Cipta.

Tenang, J.D. (2007). Jurus pintar main bola. Bandung: Mizan. 
Jurnal AUDHI, Vol. 1, No. 2, Januari 2019

Tenang, J.D. (2008). Mahir bermain futsal. Bandung: Mizan.

Wiyani, N.A. (2013). Membumikan pendidikan karakter di SD. Yogyakarta: Ar-Ruzz Med 